\title{
Accounting
}

\section{Accounting conservatism: Does business strategy and investment level matter?}

\author{
Nasr Taha Hassan ${ }^{\text {a* }}$
}

“Associate Professor, Prince Sattam Bin Abdulaziz University, Saudi Arabia

\begin{tabular}{l}
\hline C H R O N I C L E \\
\hline Article history: \\
Received: January 1, 2021 \\
Received in revised format: \\
January 232021 \\
Accepted: February 10, 2021 \\
Available online: \\
February 10, 2021 \\
\hline Keywords: \\
Business strategy \\
Accounting conservatism \\
Investment level \\
Saudi business environment \\
\end{tabular}

\section{A B S T R A C T}

\begin{abstract}
This study aims to contribute to the ongoing debate over accounting conservatism through examining whether the corporate strategy can provide a logical justification for the conservatism, and whether this justification is consistent with or contradicts the contractual justification. In this context, the study examines the impact of corporate strategy on the level of conservatism in financial statements, and the impact of the level of conservatism on corporate investment level. Using data from a sample of non-financial Saudi listed companies, the results show that prospector companies are more likely to provide more conservative financial statements, and the level of conservatism influences investment level. The results also show that the integration between corporate strategy and the level of conservatism influence the level of investment. These results suggest that accounting conservatism can be explained in the context of both business strategy and contractual benefits. Also, the results imply that adopting business strategy could influence the financial reporting process.
\end{abstract}

(C) 2021 by the authors; licensee Growing Science, Canada

\section{Introduction}

Conservatism considers a controversial accounting policy and some accounting studies have been concerned with explaining the continuous use of conservatism from an economic perspective, where contractual interpretation is the most common explanation for adopting conservatism. However, in recent study, Hsieh et al. (2019) offered another explanation for accounting conservatism based on the firm's strategy. In this context, the current study analyses the complementarity or contradiction between the two interpretations to provide a broader and deeper explanation of the accounting conservatism in Saudi business environment. The study addresses whether the corporate strategy implies a logical motive to produce conservative financial reports, and whether that motivation is consistent with the economic justification of conservatism in terms of its impact on the corporate investment level.

Business strategy determines, to a large extent, the firm's identity and affects the firm's choices during its life including choices within the financial reporting process. Conservatism has been removed from the conceptual framework, as it harms the concept of neutrality of financial information (FASB, 2010; IASB, 2010). However, neutrality can be considered as a desirable feature of financial reporting under the risk conditions, while under conditions of uncertainty; decisions must reflect a measure of caution (Hsieh et al., 2019). Therefore, uncertainty conditions can justify the accounting conservatism which can be considered as a caution practice. In this context, some studies indicated that the strategic orientation largely determines the nature of the environment in which the company operates, as companies that follow the pattern of the prospector strategy have high levels of uncertainty environment while companies that follow the pattern of defender strategy have a lower level of uncertainty

* Corresponding author.

E-mail address: n.arafa@psau.edu.sa (N. T. Hassan) 
environment (Simons, 1987; Govindarajan, 1986, 1988; Gupta, 1987; Miller, 1988; Miller et al., 1988). Consequently, the type of business strategy could determine the level of accounting conservatism.

On the other side, traditionally, accounting literature justify the continuous use of accounting conservatism depending on contractual benefits, where creditors prefer a conservative financial reporting (Nikolaev, 2010; Tan, 2013) and they reward the most conservative firms in the form of easier access to finance at a lower cost (Ahmed et al., 2002; Zhang, 2008). In this context, Balakrishnan et al. (2016) suggested that the more conservative firms are more able to improve their ability to invest , and Hong et al. (2019) proposed that when firms facing challenges to finance investment opportunities due to fluctuate its internal cash flows, the conservative financial reporting can limit the reduction in investment. Consequently, accounting conservatism can be justified in the context of maintaining the corporate investment level.

The current study suggests that business strategy provides a rational motive for accounting conservatism which, in turn, considers a mechanism to support investment level. So, both business strategy and investment level provide an integrated basis to explain accounting conservatism, as strategy represents a motivation and investment level represent a consequence for conservatism. To examine this argument in the Saudi business environment, the study uses data from registered Saudi nonfinancial companies to answer the following questions:

- Does the firm's business strategy affect the level of conservatism in the financial statements?

- Does the level of conservatism in the financial statements affect the firm's investment level?

- Does the integration between strategy and conservatism affect the firm's investment level?

This study is related to the study of Hsieh et al. (2019), and the study of Balakrishnan et al. (2016), but it differs from them in some points, first: the current study provides a wider view of the interpretation of accounting conservatism. Second: The study addresses the impact of conservatism on the investment level under the normal circumstances. Third: The study shows the combined effect of both the business strategy and the level of conservatism on the investment level.

The results of the study showed that Saudi companies tend to adopt a strategic approach that is consistent with the defender strategy, and the business strategy affects the level of conservatism in the financial statements which, in turn, affects the level of company's investment. Also, the results appear the impact of the interaction between strategy orientation and level of conservatism on the investment level. These results support the argument of the current study that both business strategy and investment level provide an integrated framework to explain the accounting conservatism. In addition, the results imply some points; 1) The accounting conservatism can be considered as a mechanism to reduce the conflict between management and creditors and thus positively affect the sources of financing. 2) prospector firms tend to have a higher level of investment and face finance constraints, which drive them to increase the level of conservatism in their financial reports. 3) It is important to care about the nature of the business environment and management policies when analysing the accounting behaviour of the company.

This paper will be continued as follows, the second section addresses the previous studies and development of the hypotheses, the third section shows the research methodology and the fourth section presents the results of study.

\section{Previous studies and hypotheses}

The current study links two types of studies, first one studies related to the impact of business strategy on the financial reporting process, and another one studies related to the impact of accounting conservatism on corporate investment. Concerning the impact of business strategy on the financial reporting process, Bentley et al. (2013) indicated that firms that follow a radical strategy are more vulnerable to financial irregularities than firms that follow a defensive strategy. Some studies have examined the relation between firm's strategy and earnings management (Wu et al., 2015; Wang \& Zhao, 2018; Huang, 2019). Also, Zhang \& Xu (2019) showed that the firm's strategy influences the relationship between Executive Compensation Incentives and earnings management. In addition, Wang (2018) analyzed the relationship between the difference in the firm's strategy from the prevailing strategy in the industry and the conservatism, and found that the greater this difference, the lower the accounting conservatism.

Regarding the impact of accounting conservatism on corporate investment, Imhof (2014) showed that higher levels of conservatism reduce the sensitivity of investment to cash flows. Also, Hong et al. (2019) indicated that conservatism reduces the negative relationship between investment and fluctuation in cash flows by facilitating access to external financing sources. Balakrishnan et al. (2016) examined the effect of conservatism on the level of investment in the period of the global financial crisis, and they found that the less conservative companies practiced a significant reduction in investment activities. Nakano et al. (2014) differentiated between the conditional and unconditional conservatism, and they found that firms that provide a higher level of conditional conservatism are more likely to limit investment and their investments are less risky, whereas firms that 
provide a higher level of unconditional conservatism have a higher investment level and their investments are riskier. Ji \& Ryu (2019) found a relationship between conservatism and foreign investment as firms with long-term foreign investment provide higher levels of conservatism, and Chiou \& Chang (2020) indicated that conservatism improves the quality of information and reduces the risks faced by investors.

\section{1 corporate strategy and conservatism}

Business strategy is one of the corporate characteristics that is chosen at an early stage and represents an essential factor to determine the corporate identity. Therefore, it can determine, to a large extent, the choices that the company makes during its life including choices related to the financial reporting, and consequently the level of conservatism in the financial statements. The business strategic orientations can be categorized into two main patterns, which are the prospector firms and the defender firms. Political cost theory suggests that highly profits and significantly growth firms, the characteristics of prospector firms, attract the attention of external parties in general (public opinion and regulators), which results in additional burdens for these firms. Therefore, managers need to deal with external parties concerns to alleviate the burdens on them, and this may be done in the form of public relations management or social work. It may also be done by adopting conservative accounting policies that improve the parties' view of the company (Houqe et al., 2013), which leads to an increase in the level of accounting conservatism.

On the other hand, Hsieh et al. (2019) has suggested that the different perspectives concerning accounting conservatism is depending on the analysis under the risk conditions, while a distinction must be made between risk and uncertainty conditions according to the economic theory (Heinsalu, 2012). Some studies indicated that the strategic orientation determines the nature of the environment in which the company operates, as prospectors' companies operate in an uncertainty environment while defenders' companies have a lower level of uncertainty conditions (Simons,1987; Govindarajan, 1986, 1988; Gupta, 1987; Miller, 1988; Miller et al., 1988). The strategy adopted by the firm is stable over time (Brynjolfsson \& Milgrom, 2013), which support the perspective that business strategy determines the nature of the circumstances in which the firm operates. Under uncertainty conditions, caution can be considered as a desirable characteristic, as it improves the quality of decisions by making them more appropriate to the lack of knowledge (Hansen \& Sargent, 2008; Roy, 2010). While under risk circumstances, caution can be considered as an attempt to avoid risk, and in the competitive market, firms that avoid risk retreat in front of firms that bear the risk and therefore caution is an undesirable feature (Hsieh et al., 2019). Accordingly, prospectors' firms tend to adopt cautionary practices, which can be reflected in the financial reporting process in the form of an increased level of conservatism.

Based on that, the use of the accounting conservatism can be understood and justified in the context of the firm's strategic orientation, where the following assumption can be formulated:

$\mathbf{H}_{1}$ : The firms that adopt the prospector strategy provide a higher level of conservatism in their financial statements than the firms that adopt the defensive strategy.

\section{2 conservatism and investment level}

Investment plays a fundamental role in the firm's growth and creating new value for the owners. According to the contractual interpretation of conservatism, it improves the firm's ability to borrow and the terms of borrowing and consequently helps to limit the trend to reduce the investment (Balakrishnan et al., 2016). Some studies indicated that creditors prefer a conservative financial reporting, Gox and Wagenhofer (2009) presented an analytical model that shows that a conservatism is an ideal accounting policy for firms with financial constraints, Kravet (2014) indicates that a conservative financial reporting helps Creditors to monitor the firm's investment decisions, Donovan et al. (2015) provided evidence that creditors of more conservative firms have a high coverage rate, Hui et al. (2012) presented evidence that long-term suppliers and customers prefer the conservative reporting. Other studies indicated that creditors reward more conservative borrowers with lower interest rates (Wittenberg-Moerman, 2008; Gormley et al., 2012; Haw et al., 2014).

However, there is an opposing perspective that suggests that conservatism includes a degree of bias that leads investors and creditors to wrong decisions. Gigler et al. (2009) indicated that the conservatism increases the possibility of false warnings, which leads to reducing the efficiency of debt contracts. Ishida \& Ito (2014) found a negative correlation between conditional conservatism and the investment level, and a positive correlation between non-conditional conservatism and the investment level. The current study examines the contractual explanation of accounting conservatism through examining the association between conservatism and investment level, where it is expected that accounting conservatism leads to maintain and increase investment level. Therefore, the following hypothesis can be examined:

$\mathbf{H}_{2}$ : There is a positive association between the conservatism level in the financial statements and the firm's investment level. 


\subsection{Strategy, conservatism and investment level}

Managers tend to coordinate performance in the way that reduces financial constraints and access to finance at a lower cost (Lan \& Yang, 2014), therefore the firm's strategy greatly influences financing requirements and constraints (Wang \& Zaho, 2018). Luo and Chen (1997) pointed out the link between the business strategy and the firm's investment strategy, and Lin et al. (2021) indicated that business strategy plays a modified role in the relationship between corporate social responsibility and investment efficiency. Navissi et al. (2017) found that prospector firms tend to over investment, while defender firms tend to under investment, indicating the need of prospector firms to finance. Firms pursuing prospector-type strategy largely need more financing to support product development and increase energy for market leadership (Ittner et al., 1997), and these firms are usually exposed to a higher degree of risk and thus are exposed to more financial restrictions (Wang \& Zhao, 2018).

Also, the organizational theory suggests that prospector firms are more likely to have a weaker internal control system than defender firms (Bentley-Goode et al., 2017), and some studies have indicated that poor internal oversight is associated with an increase in debt costs (Ashbaugh-Skaife et al., 2009; Dhaliwal et al., 2011; Kim et al., 2011). Consequently, prospector firms can have problems accessing finance, which negatively influences the level of investment. Given that conservatism, in the context of a contractual interpretation, is seen as a mechanism that facilitates access to funding sources, there is a link between the prospector strategy and the level of conservatism in the financial statements, which positively affects the level of investment.

Thus, in the context of current study, it can be argued that both business strategy and contractual issues are integrated to interpret accounting conservatism, where prospector firms tend to provide conservative financial statements as a mechanism for both dealing under the uncertainty conditions that characterize the work environment of these firms, and to maintain the required investment level of those firms. Therefore, the following hypothesis can be examined:

\section{H3: The interaction between the prospector strategy and the level of conservatism positively influences the level of investment.}

\section{Method}

To achieve the objectives, the study uses data from the Saudi non-financial registered companies for the year 2018. The initial sample is 125 companies in 16 sectors, and according to the data availability, some companies were excluded, so that the final sample was 103 companies. The data was mainly manually collected from annual reports and were processed by STATA program.

\subsection{Variables measurement}

The main variables of study are corporate strategy and the level of accounting conservatism in financial statements. Concerning corporate strategy, I used the approach of Bentley et al (2013) and Hsieh et al. (2019), where a compound measure of six variables that are measured as an average of the previous five years. The variables are: the rate of research and development expenditures to sales, the average number of employees to sales, the percentage of change in sales during one year, the rate of marketing and administrative expenses to sales, Standard deviation of the number of employees, the average of the net properties, plant and equipment to total assets. These measures are ranked into quintiles, where Observations in the highest (lowest) quintile receive a score of five(one). The firm's strategy is measured as the sum of the six scores, so that the strategy index ranges between 6 and 30. Higher scores represent a prospector-oriented strategy and lower scores represent a defenderoriented strategy.

Regarding accounting conservatism, it can be measured through three variables, 1) the ratio of total accruals to total assets multiplied by -1 , and this variable is calculated as an average for the current year and the previous two years. Total accruals are calculated as net income before extraordinary items - operating cash flows + depreciation expense. 2) The ratio of non-operating accruals to total assets -1 for the current year and multiplied by -1 . Non-operating accruals are calculated as net income + depreciation - operating cash flows - change in accounts receivable - change in inventory - change in prepaid expenses + change in accounts payable + change in due taxes payable. 3) The difference between the skewness of operating cash flows and the skewness of net income before extraordinary items, and this variable is measured over the previous twenty quarters (Beatty et al., 2008). These measures are grouped to create an index to measure the level of accounting conservatism.

\subsection{Models}

The OLS regression model is used to examine the hypotheses. Concerning the first hypothesis, the following model can be used (Hsieh et al., 2019): 
where the dependent variable CONSt expresses the level of conservatism in the financial statements in year $t$, and the independent variable STRATEGY $\mathbf{t}_{\mathbf{t}}$ expresses the strategic direction adopted by the company in year $t$. The control variables include: the size of the company (CS) measured by the natural logarithm of the total assets, the leverage rate (LEV), the loss index (LOSS) which is an dummy variable that takes the value 1 if the company's result is a loss and takes the value 0 otherwise, the nature of the activity (TA) which is an dummy variable that takes the value 1 for companies in the industrial sector, the value is 0 otherwise. Concerning the level of governance quality (CG), the index that takes the value from 0 to 6 can be used. The governance index is based on accumulating points for the company according to the following attributes of governance quality: More than half of the board of directors are independent directors (1) or not (0), There is one person who occupies the positions of CEO and chairman of the board (0) or not (1), the audit committee consists of at least three directors (1) or not (0), the audit committee is entirely composed of independent managers (1) or not (0), the audit committee contains at least one of the financial experts (1) or not (0), the audit committee meets at least 4 times annually (1) or not (0).

To examine the first hypothesis, the coefficient $\boldsymbol{\beta}_{\mathbf{1}}$ is of interest, as it is expected to take a significant positive value. Regarding the relationship between conservatism and investment level, the following model can be used (Balakrishnan et al., 2016; Nakano et al., 2014).

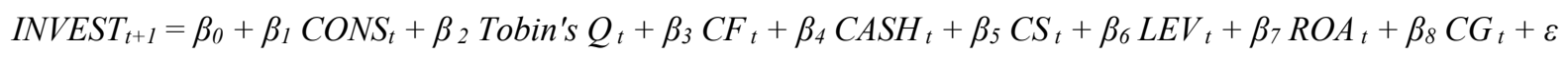

where the dependent variable INVEST $\mathbf{t}_{\mathbf{t}+\mathbf{1}}$ expresses the company's investment level in year $\mathrm{t}+1$ measured by the ratio of net investment (change in fixed assets + research and development expenses) to total assets, the independent variable CONSt expresses the level of conservatism in the financial statements, and the control variables include: Cash Flows (CF), Cash and cash Equivalent (CASH), corporate Size (CS), Leverage Ratio (LEV), return to Assets rate (ROA), and Governance Level (CG). The corporate value (Tobin's Q) which is calculated as follows:

The book value of the assets + the market value of shares - the book value of shares - deferred tax/ Book value of assets.

To test the second hypothesis, the coefficient $\beta 1$ is of interest, as it is expected to take a significant positive value.

Regarding the interaction between conservatism, strategy and investment, interactive variable STAR * CONS that expresses the interaction between strategy and the level of conservatism can be used in Model 2 . To test the hypothesis3, the coefficient $\beta 1$ will be of interest, as it is expected to take a positive significant value.

\section{Results}

\subsection{Descriptive statistics}

Table 1 presents the descriptive statistics for the variables. Regarding corporate strategy, the results show that the average indicator of strategy is approximately 16.6, indicating that the dominant strategic orientation for Saudi companies is defense strategy.

\section{Table 1}

Descriptive statistics

\begin{tabular}{|c|c|c|c|c|c|}
\hline $\begin{array}{l}\text { Panel 1: } \\
\text { Variables }\end{array}$ & Obs. & Mean & Std. Dev. & Min. & Max. \\
\hline CONS & 103 & 5.351313 & 1.262649 & 3.034 & 9.979 \\
\hline STRATEGY & 103 & 16.58438 & 4.708965 & 8 & 26 \\
\hline INVESTLEVEL & 103 & 0.281181 & 0.0986534 & 0.112 & 0.441 \\
\hline CS & 103 & 9.405469 & 2.103403 & 4.75 & 12.38 \\
\hline LEV & 103 & 6.710312 & 2.677425 & 2.14 & 10.96 \\
\hline CG & 103 & 5.190625 & 0.8566674 & 4 & 6 \\
\hline Tobin's Q & 103 & 2.002016 & 1.432361 & 0.121 & 4.98 \\
\hline CF & 103 & 25.08708 & 16.65985 & -0.174 & 48.64 \\
\hline CASH & 103 & 5.644033 & 2.057243 & 2.55 & 9.003784 \\
\hline ROA & 103 & 0.2104921 & 0.1729832 & -0.247 & 0.514 \\
\hline \multicolumn{6}{|l|}{ Panel 2: } \\
\hline Variables & & 0 & \multicolumn{3}{|c|}{1} \\
\hline Loss & & $68(66 \%)$ & \multicolumn{3}{|c|}{$35(34 \%)$} \\
\hline TA & & $47(45.6 \%)$ & \multicolumn{3}{|c|}{$56(54.4 \%)$} \\
\hline
\end{tabular}


To clarify that result, companies can be classified according to their results in strategy index, where companies which their indicator reaches 18 or less represent defender companies, while companies which their indicator more than 18 represent the prospector companies. According to this classification, the prospector companies are 39 companies (37.9\%), and defender companies are 64 companies (62.1\%). These numbers prove that most companies in the Saudi business environment tend to adopt defensive strategy. Concerning investment level and conservatism, the results show that the average of investment level is approximately $28 \%$, and the average indicator of conservatism is 5.35 . Regarding the control variables, the average of natural logarithm of the total assets is 9.4, the average of leverage rate is 6.7, the average value of Tobin's $Q$ is 2 , and the average profit rate is $21 \%$. In addition, the average of governance quality index is 5.2, which reflects that Saudi companies tend to adopt high quality governance mechanisms.

\subsection{Hypotheses test}

To examine the first hypothesis, table 2presents the regression results for Model 1 . The results show a positive association between the level of conservatism and corporate strategy, indicating that an increase in the company's index of strategy leads to an increase in the level of conservatism in the financial statements. This result suggests that prospector companies are more likely to increase the level of conservatism in their financial statements, which leads to acceptance of the first hypothesis. This result presents empirical evidence from Saudi business environment supporting the argument of Hsieh et al. (2019) that corporate strategy can explain the level of accounting conservatism. This argument clarifies that the approach upon which the professional organizations relied to exclude conservatism from the conceptual framework did not take into account the nature of the environment in which the company operates, where the perspective that conservatism harms the neutrality of information can be accepted under risk circumstances. However, this perspective neglects uncertain circumstances where caution is considered a desirable feature in administrative behaviour. Consequently, companies operating under conditions of uncertainty will prefer to present more conservative financial reports based on the caution characteristic. In this context, the business strategy adopted by the company can determine - to a large extent- the nature of the environment in which the company operates, where the conceptual basis on which the prospector strategy reflects the conditions of uncertainty. Therefore, prospector-oriented companies are more likely to present conservative financial reports as a practice of caution, which is supported by the result of the study.

Table 2

Regression results between strategy and conservatism

\begin{tabular}{|c|c|c|c|c|}
\hline & Coef. & Std. Err. & $\mathbf{t}$ & $\mathbf{P}>|\mathbf{t}|$ \\
\hline STRATEGY & 0.1623764 & 0.0340468 & 2.83 & 0.042 \\
\hline CS & -0.082809 & 0.1221821 & -0.68 & 0.501 \\
\hline LEV & 0.0403309 & 0.1068177 & 3.38 & 0.07 \\
\hline LOSS & -0.4050106 & 0.6650197 & -0.61 & 0.545 \\
\hline TA & -0.2550095 & 0.2675957 & -1.95 & 0.034 \\
\hline CG & 0.3583024 & 1.018597 & 2.35 & 0.026 \\
\hline Prob $>$ F & \multicolumn{4}{|c|}{0.0223} \\
\hline Adj R-squared & \multicolumn{4}{|c|}{0.1123} \\
\hline
\end{tabular}

Concerning hypothesis 2, Table 3 presents the regression results for model 2. The results show a positive association between conservatism and the level of investment, indicating that the increase in the level of conservatism in the financial statements leads to an increase in the level of investment, which leads to accept the second hypothesis. This result supports - to a large extent - the contractual justification of conservatism, where conservatism helps to access financing resources and thus maintains the level of investment.

Table 3

Regression results between conservatism and investment level

\begin{tabular}{|c|c|c|c|c|}
\hline & Coef. & Std. Err. & $\mathbf{t}$ & $\mathbf{P}>|\mathbf{t}|$ \\
\hline CONS & 0.0209036 & 0.0145247 & 2.44 & 0.022 \\
\hline Tobin's Q & 0.0062041 & 0.0172103 & 1.36 & 0.073 \\
\hline CF & 0.00142 & 0.0009379 & 2.51 & 0.020 \\
\hline CASH & -0.0315477 & 0.0198829 & -0.59 & 0.188 \\
\hline CS & 0.0791313 & 0.0852421 & 0.93 & 0.406 \\
\hline LEV & 0.0112576 & 0.0333858 & 1.34 & 0.075 \\
\hline ROA & -0.5260281 & 0.3885962 & -1.35 & 0.024 \\
\hline CG & 0.1485652 & 0.0772391 & 1.92 & 0.127 \\
\hline Prob $>$ F & \multicolumn{4}{|c|}{0.0143} \\
\hline Adj R-squared & \multicolumn{4}{|c|}{0.8820} \\
\hline
\end{tabular}


Regarding the interaction between strategy and investment to interpret accounting conservatism, the impact of both strategy and conservatism on the investment level can be examined. An interactive variable STAR $\times$ CONS that expresses the interaction between the strategy indicator and the level of conservatism has been used in model 2 . The regression results, in table 4 , show a positive association between the interactive variable and the level of investment, indicating that prospector firms with high level of conservatism in the financial statements are more likely to maintain the investment level, which leads to acceptance of the third hypothesis. The positive association between interactive variables and investment level suggest that prospector firms use conservatism for dual purposes, to face their environmental conditions - uncertainty - and maintain their level of investment. Accordingly, this result provides empirical evidence that accounting conservatism can be better explained in the context of business strategy and contractual benefits.

Table 4

Regression results concerning the impact of both strategy and conservatism on the investment level

\begin{tabular}{|c|c|c|c|c|}
\hline & Coef. & Std. Err. & $\mathbf{t}$ & $\mathbf{P}>|\mathbf{t}|$ \\
\hline STAR $\times$ CONS & 0.0006297 & 0.000887 & 1.71 & 0.050 \\
\hline Tobin's Q & 0.0051216 & 0.0199566 & 0.26 & 0.808 \\
\hline CF & 0.0009259 & 0.0009847 & 1.94 & 0.039 \\
\hline CASH & 0.0129532 & 0.0203418 & 1.64 & 0.055 \\
\hline CS & 0.0287706 & 0.0923774 & 1.31 & 0.076 \\
\hline LEV & -0.0139355 & 0.0363541 & -0.38 & 0.717 \\
\hline ROA & 0.2860339 & 0.4271826 & 0.67 & 0.533 \\
\hline CG & 0.0789617 & 0.0805117 & 1.98 & 0.037 \\
\hline Prob $>$ F & \multicolumn{4}{|c|}{0.0104} \\
\hline Adj R-squared & \multicolumn{4}{|c|}{0.8486} \\
\hline
\end{tabular}

\section{Sensitivity analysis}

Sensitivity analysis refers to an analysis of the impact of change in some variables measurements on the results of the study. Sensitivity analysis contains two points. First: Measuring the strategy variable as a dummy variable takes the value 1 if the strategy indicator of the company is greater than 18 and takes the value 0 if the total of the indicator is 18 or less. The regression results of model 1(not tabulated) indicated a positive association between strategy and conservatism (Coef. 0.2014754), indicating that prospector companies are more likely to provide conservative financial statements, which consistent with and supports the study results. Second: Instead of using the interactive variable STAR $\times$ CONS to test the interaction between strategy, conservatism and investment, the total sample can be divided, according to the dummy variable of the strategy, into two samples, one of which represents the prospector companies (39 companies) and the other represent defender companies (64 companies). Model 2 is used in the two samples with replacing the interactive variable with the conservatism variable, and comparing the regression results in two samples. Although the regression results for the two samples (not tabulated) show a positive association between conservatism and the level of investment in the two samples, the regression coefficient in the sample of the prospector companies (Coef. 0.2246485) is greater than the defender companies (Coef. 0.1604792). This result reflects that the impact of conservatism on investment level is greater in the prospector companies than defender companies, which supports the results of the study concerning the interaction between strategy and investment level to explain the accounting conservatism.

\section{Conclusion}

This study presented concurrent evidence that the accounting conservatism can be interpreted in the context of both environmental conditions and contractual advantages in a way that demonstrates the consistency between them. These evidences suggest that the uncertainty conditions that arise from the nature of prospector strategy represent a motive to increase the level of accounting conservatism as indicator of the caution that is considered as required characteristic under these conditions. On the other hand, the accounting conservatism can be considered - to a large extent - as a mechanism that helps the company to maintain the investment level. In addition, the results provided evidence of an interaction between business strategy, investment, and conservatism. Therefore, it can be concluded that both corporate strategy and investment level are two linked bases to understand why conservatism is still an important accounting practice.

\section{Acknowledgement}

This paper financially supported by deanship of scientific research, Prince Sattam Bin Abdulaziz University, under the research project number 2020/02/17101. 


\section{References}

Ahmed, A. S., Billings, B. K., Morton, R. M., \& Stanford-Harris, M. (2002). The role of accounting conservatism in mitigating bondholder-shareholder conflicts over dividend policy and in reducing debt costs. The Accounting Review, 77(4), 867-890.

Ashbaugh-Skaife, H., Collins, D. W., Kinney Jr, W. R., \& LaFond, R. (2009). The effect of SOX internal control deficiencies on firm risk and cost of equity. Journal of Accounting Research, 47(1), 1-43.

Balakrishnan, K., Watts, R., \& Zuo, L. (2016). The effect of accounting conservatism on corporate investment during the global financial crisis. Journal of Business Finance \& Accounting, 43(5-6), 513-542.

Beatty, A., Weber, J., \& Yu, J. J. (2008). Conservatism and debt. Journal of accounting and economics, 45(2-3), 154-174.

Bentley-Goode, K. A., Newton, N. J., \& Thompson, A. M. (2017). Business strategy, internal control over financial reporting, and audit reporting quality. Auditing: A Journal of Practice \& Theory, 36(4), 49-69.

Bentley, K. A., Omer, T. C., \& Sharp, N. Y. (2013). Business strategy, financial reporting irregularities, and audit effort. Contemporary Accounting Research, 30(2), 780-817.

Brynjolfsson, E., \& Milgrom, P. (2013). Complementarity in organizations. The handbook of organizational economics, 11-55.

Chiou, B. H., \& Chang, S. H. (2020). Influence of Investment Efficiency by Managers and Accounting Conservatism on Idiosyncratic Risks to Investors. Advances in Management and Applied Economics, 10(1), 105-133.

Dhaliwal, D., Hogan, C., Trezevant, R., \& Wilkins, M. (2011). Internal control disclosures, monitoring, and the cost of debt. The Accounting Review, 86(4), 1131-1156.

Donovan, J., Frankel, R. M., \& Martin, X. (2015). Accounting conservatism and creditor recovery rate. The Accounting Review, 90(6), 2267-2303.

Financial Accounting Standards Board (FASB), (2010), Statement of Financial Accounting Concepts No.8, Conceptual Framework for Financial Reporting, Chapter 1, The Objective of General Purpose Financial Reporting, and Chapter 3, Qualitative Characteristics of Useful Financial Information, FASB.

Gigler, F., Kanodia, C., Sapra, H., \& Venugopalan, R. (2009). Accounting conservatism and the efficiency of debt contracts. Journal of Accounting Research, 47(3), 767-797.

Gormley, T. A., Kim, B. H., \& Martin, X. (2012). Do firms adjust their timely loss recognition in response to changes in the banking industry?. Journal of Accounting Research, 50(1), 159-196.

Govindarajan, V. (1986). Decentralization, strategy, and effectiveness of strategic business units in multibusiness organizations. Academy of Management Review, 11(4), 844-856.

Govindarajan, V. (1988). A contingency approach to strategy implementation at the business-unit level: integrating administrative mechanisms with strategy. Academy of management Journal, 31(4), 828-853.

Goex, R. F., \& Wagenhofer, A. (2009). Optimal impairment rules. Journal of Accounting and Economics, 48(1), 2-16.

Gupta, A. K. (1986). Matching managers to strategies: Point and counterpoint. Human Resource Management, 25(2), 215-234.

Hansen, L. P. \& Sargent, T. J. (2008). Robustness. Princeton, NJ, Princeton University Press.

Haw, I. M., Lee, J. J., \& Lee, W. J. (2014). Debt financing and accounting conservatism in private firms. Contemporary Accounting Research, 31(4), 1220-1259.

Heinsalu, S. (2012). Equivalence of the information structure with unawareness to the logic of awareness. Journal of Economic Theory, 147(6), 2453 - 2468.

Hong, H. A., Kim, Y., \& Lobo, G. J. (2019). Does Financial Reporting Conservatism Mitigate Underinvestment?. Journal of Accounting, Auditing \& Finance, 34(2), 258-283.

Houqe, M. N., Kerr, R., \& Monem, R. (2013). Business strategy and earnings quality.

Hsieh, C. C., Ma, Z., \& Novoselov, K. E. (2019). Accounting conservatism, business strategy, and ambiguity. Accounting, Organizations and Society, 74, 41-55.

Huang, X. (2019), Corporate Strategic Difference, High Audit Quality and Earnings Quality, 9th International Conference on Education and Social Science (ICESS 2019).

Hui, K. W., Klasa, S., \& Yeung, P. E. (2012). Corporate suppliers and customers and accounting conservatism. Journal of Accounting and Economics, 53(1-2), 115-135.

Imhof, M. J. (2014). Timely loss recognition, agency costs and the cash flow sensitivity of firm investment. Academy of Accounting and Financial Studies Journal, 18(3), 45.

International Accounting Standards Board (IASB), (2010), Conceptual Framework for Financial Reporting 2010, IASB.

Ishida, S., \& Ito, K. (2014). The effect of accounting conservatism on corporate investment behavior. In International Perspectives on Accounting and Corporate Behavior (pp. 59-80). Springer, Tokyo.

Ittner, C. D., Larcker, D. F., \& Rajan, M. V. (1997). The choice of performance measures in annual bonus contracts. Accounting Review, 72(2), 231-255.

Ji, S. H., \& Ryu, Y. R. (2019). Investment tendency of foreign investor and accounting conservatism. Journal of Digital Convergence, 17(3), 153-160.

Kim, S. R. N., Yang, D. H., \& Cho, K. H. (2011). The impact of the agency cost on accounting conservatism. Korean Accounting Review, 36(3), 65-102. 
Kravet, T. D. (2014). Accounting conservatism and managerial risk-taking: Corporate acquisitions. Journal of Accounting and Economics, 57(2-3), 218-240.

Lan, B. \& Yang, F. (2014). Debt Contract and Earnings Management. Journal of Research on Financial and Economic Issues, 2, 102-107.

Lin, Y. E., Li, Y. W., Cheng, T. Y., \& Lam, K. (2021). Corporate social responsibility and investment efficiency: Does business strategy matter?. International Review of Financial Analysis, 73, 101585.

Luo, Y., \& Chen, M. (1997). Business Strategy, Investment Strategy, and Performance of International Joint Ventures. Cooperative Strategies: Asian Pacific Perspectives, (3), 341.

Miller, D. (1988). Relating Porter's business strategies to environment and structure: Analysis and performance implications. Academy of management Journal, 31(2), 280-308.

Miller, D., Dröge, C., \& Toulouse, J. M. (1988). Strategic process and content as mediators between organizational context and structure. Academy of Management Journal, 31(3), 544-569.

Nakano, M., Otsubo, F., \& Takasu, Y. (2014). Effects of accounting conservatism on corporate investment levels, risk taking, and shareholder value (No. 14-E-10). Institute for Monetary and Economic Studies, Bank of Japan.

Navissi, F., Sridharan, V. G., Khedmati, M., Lim, E. K., \& Evdokimov, E. (2017). Business strategy, over-(under-) investment, and managerial compensation. Journal of Management Accounting Research, 29(2), 63-86.

Nikolaev, V. V. (2010). Debt covenants and accounting conservatism. Journal of Accounting Research, 48(1), $137-176$.

Roy, B. (2010), Robustness in operational research and decision aiding, A multifaceted issue. European Journal of Operational Research, 200(3), 629 - 638.

Simons, R. (1987), Accounting control systems and business strategy, An empirical analysis. Accounting, Organizations and Society, 12, 357-374.

Tan, L. (2013). Creditor control rights, state of nature verification, and financial reporting conservatism. Journal of Accounting and Economics, 55(1), 1-22.

Wang, R. (2018). Strategic Deviance and Accounting Conservatism. American Journal of Industrial and Business Management, 8(05), 1197.

Wang, X., \& Zhao, X. (2018, May). Corporate Strategy and Earnings Management. In 2018 International Conference on Advances in Social Sciences and Sustainable Development (ASSSD 2018) (pp. 243-246). Atlantis Press.

Wittenberg-Moerman, R. (2008). The role of information asymmetry and financial reporting quality in debt trading: Evidence from the secondary loan market. Journal of Accounting and Economics, 46(2-3), 240-260.

Wu, P., Gao, L., \& Gu, T. (2015). Business strategy, market competition and earnings management. Chinese Management Studies, 9(3), 401..

Zhang, J. (2008). The contracting benefits of accounting conservatism to lenders and borrowers. Journal of accounting and economics, 45(1), 27-54.

Zhang, R. \& Xu, F. (2019). Corporate Strategy, Executive Compensation Incentives and Earnings Management. Finance, 9(1), $1-10$. 


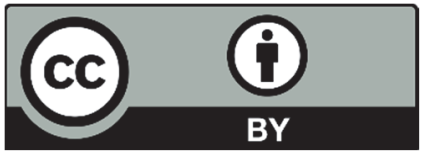

(C) 2021 by the authors; licensee Growing Science, Canada. This is an open access article distributed under the terms and conditions of the Creative Commons Attribution (CC-BY) license (http://creativecommons.org/licenses/by/4.0/). 